\title{
Efficacy of different entomopathogenic fungal isolates against chilli aphid, Myzus Persicae (Sulz.)
}

\author{
S. Sumaiya Parveen*, R. Philip Sridhar, S. Usha Nandhini \\ Karunya Institute of Technology and Sciences, Coimbatore, Tamil Nadu, India \\ *Corresponding author: Karunya Institute of Technology and Sciences, Coimbatore. \\ Email: ssumaiyasaleem@gmail.com
}

\begin{abstract}
In recent years, microbial control of insect pests is becoming popular as insect pathogens such as bacteria, viruses, fungi and nematodes serve as potential bioagents in pest management. Among the different microbial agents, entomopathogenic fungi (EPF) are gaining importance in pest control. They can be easily mass cultured on artificial media without affecting their virulence at a cheaper cost. They are highly species specific with minimal impact on non-target organisms. The current study aimed to study the efficacy of entomopathogenic fungal isolates against aphid, Myzus Persicae (Sulz.) in chilli. Laboratory and field experiments were conducted to evaluate the pathogenicity of Beauveria bassiana, Metarhizium anisopliae and Lecanicillium lecanii against chilli aphid. From the study it is revealed that B. bassiana @ $10^{8}$ spores $\mathrm{ml}^{-1}$ were found to be effective and found to be more superior to the other entomopathogenic fungal isolates viz., Metarhizium anisopliae and Lecanicillium lecanii against chilli aphid.
\end{abstract}

Keywords: Entomopathogenic fungi, Chilli, Aphid, Beauveria bassiana, Metarhizium anisopliae, Lecanicillium lecanii

\section{INTRODUCTION}

Chilli is the most common spice crop. Among the different pests, chilli aphid, Myzus persicae (Sulz.) alone causes 20 to 40 per cent yield loss [1,2]. It is a polyphagous pest and besides chilli it attacks a large number of host plants viz., Tomato, broccoli, cabbage, carrot, cauliflower, eggplant, green beans, lettuce, mustards, papaya, peppers and sweet potato. The aphid causes both qualitative and quantitative losses in the seed yield and crop production by different ways include: Nutrient drain which cause direct reduction of plant productivity, transmission of viruses, phytotoxicity as a result of saliva toxins and excretion of honeydew leading to the development of black sooty mold and leaf shedding [3].

M. persicae is highly susceptible to chemical insecticides and some of the recommended chemicals for its management are malathion, phosalone, monocrotophos, dimethoate, methyl demeton and acephate $[4,5,6]$. However, their effectiveness is temporary and the aphid reappears after 2-3 weeks of spraying, besides, these insecticides are also highly toxic to the predators. Due to the negative impact of the chemical insecticides, the need for effective, safer, specific and sustainable method of aphid management arose. Biopesticides such as virus, bacteria and fungi play a major role in insect pest management. Unlike virus and bacteria, the fungal biocontrol agents do not have to be ingested to infect their host but invade directly through the cuticle and so can potentially be used for the control of sucking pests like aphid. In addition, due to their high degree of specificity, potential activity and environmental safety, recently more attention has been given to insect pest management with entomopathogenic fungi viz., Beauveria bassiana (Balsamo) Vuillemin, Metarhizium anisopliae (Metchinkoff) Sorokin and Lecanicillium lecanii (Zimm.) Zare and Gams. Keeping this in view, the present study has been focused to study the effect of various entomopathogenic fungal isolates against chilli aphid.

\section{A. Maintenance of fungal isolates}

\section{MATERIALS AND METHODS}

Pure cultures of the entomopathogenic fungi Beauveria bassiana, Metarhizium anisopliae and Lecanicillium lecanii were obtained from the National Bureau of Agricultural Insect Resources (NBAIR). These fungi were then subcultured in SMA + Y media, incubated at $25 \pm 1^{\circ} \mathrm{C}$ for ten days and stored in refrigerator at $5^{\circ} \mathrm{C}$. All the fungal isolates were subcultured once in three weeks. To maintain the virulence, after six subculturing all the fungal isolates were subjected to pathogenicity test and again reisolated for further studies [7].

\section{B. Preparation of spore concentrations of the fungal isolates}

Fungal isolates were cultured in $100 \mathrm{ml} \mathrm{SMA}+\mathrm{Y}$ liquid medium in $250 \mathrm{ml}$ conical flask and incubated at room temperature for 10 days. After sporulation of the fungal isolates, it was ground in ordinary mixer and made into liquid spore suspension. This was filtered through double layered muslin cloth to remove the mycelial mat. The suspension was shaken thoroughly with a drop of teepol solution in order to disperse the spores in the solution. The spore count in the suspension was assessed by using a haemocytometer [8].

\section{Pathogenicity test}

For bioassays against chilli aphid, the chilli leaves were placed individually on wet cotton swab with filter paper in a Petri dish. Thirty apterous aphids were released separately in each piece of leaf. The fungal 
spore suspension was collected from ten day old respective cultures by scraping the surface of the culture plates with a sterile scalpel and suspending them in 0.05 per cent aqueous Tween 80 [9]. The spore load was assessed using Neubauer haemocytometer. From the stock solution, further dilutions were made to obtain the required concentrations for further studies. Spore concentration of $1 \times 10^{8}$ spores $\mathrm{ml}^{-1}$ was prepared and ten ml was sprayed separately using atomizer. Aphids sprayed with 0.05 per cent Tween 80 solution served as check.

Mortality of aphids were recorded separately at $24 \mathrm{~h}$ interval up to seven days. Dead aphids were collected daily, placed in Petridish containing a moist filter paper and kept in humid chamber. The dead aphids that produced mycelial growth were considered for the mortality count. Mortality data was corrected with control mortality by using Abbott's formula [10]. The data was then analysed by probit analysis [11] and the Median Lethal Concentration (LC50) and the Median Lethal Time (LT50) values were computed by using the statistical computer programme, Statistical Package of Social Sciences (SPSS).

\section{Field efficacy of fungal pathogens on chilli aphid}

A field experiment was conducted to evaluate the pathogenicity of fungal pathogens viz., B. bassiana, M. anisopliae and L. lecanii on M. persiace. In the experiment, monocrotophos $36 \mathrm{EC}$ and malathion $50 \mathrm{EC}$ ( $2 \mathrm{ml} /$ lit) were included as standard checks. The following treatments were imposed

\begin{tabular}{lll}
\hline & Treatments & Dose \\
\hline $\mathrm{T}_{1}$ & B. bassiana & $1 \times 10^{8}$ spores $/ \mathrm{ml}$ \\
$\mathrm{T}_{2}$ & M. anisopliae & $1 \times 10^{8}$ spores $/ \mathrm{ml}$ \\
$\mathrm{T}_{3}$ & L. lecanii & $1 \times 10^{8} \mathrm{spores} / \mathrm{ml}$ \\
$\mathrm{T}_{4}$ & Monocrotophos 36 EC & $2 \mathrm{ml} / \mathrm{lit}$ \\
$\mathrm{T}_{5}$ & Malathion 50 EC & $2 \mathrm{ml} / \mathrm{lit}$ \\
$\mathrm{T}_{6}$ & Untreated check & - \\
\hline
\end{tabular}

Two rounds of treatments were given at 14 days interval with the help of a knapsack sprayer. The first spray was given when the aphid population was high. The pre-treatment and post-treatment observations on aphid population were assessed on $0,1,3,7$ and 14 days after treatment. Ten clumps were randomly selected per plot and they were treated and tagged. Observations were made on three consecutive leaves of treated plants from top and they were stapled together for easy identification and assessed for live aphid population in three places of $4 \mathrm{~cm}^{2}$ area and the mean was calculated.

\section{A. Pathogenicity of fungal pathogens against $M$. persicae}

\section{RESULTS AND DISCUSSION}

Among the three fungal pathogens tested, B. bassiana and L. Lecanii caused mortality of M. persicae at $33.75,16.25$ per cent, respectively and $M$. anisopliae was found to be less effective as compared to other two isolates. The standard checks monocrotophos and malathion showed mortality of 84.30 and 78.75 per cent, respectively (Table 1).

\section{B. Determination of $\mathrm{LC}_{50}$ and $\mathrm{LT}_{50}$}

The data on dose-mortality and time-mortality response of $M$. persicae to $B$. bassiana and $M$. anisopliae showed significant differences in the $\mathrm{LC}_{50}$ and $\mathrm{LT}_{50}$ values (Table 2). The $\mathrm{LC}_{50}$ value of $B$. bassiana was $4.58 \times 10^{6}$ spores $/ \mathrm{ml}$ followed by $3.47 \times 10^{6}$ spores $/ \mathrm{ml}$ for $M$. anisopliae. Similarly, the $\mathrm{LT}_{50}$ values of $B$. bassiana and M. anisopliae were 73.15 and 83.11 hours, respectively. Low $\mathrm{LC}_{50}$ value of $1.2 \times 10^{4} \mathrm{spores}^{-1}$ for L. lecanii against Brevicoryne brassicae and $2.7 \times 10^{4}$ spores $\mathrm{ml}^{-1}$ against Aphis gossypii [12, 13]. The difference in the $\mathrm{LC}_{50}$ values might be due to the difference in the virulence of fungal isolates and the host species.

Similar results for B. bassiana with LT50 value of 3.17 days [14]. The LT50 value of 3.31 days obtained for L. lecanii against Aphis fabae [15] also agree with the present finding. M. anisopliae and $C$. oxysporum recorded higher LT50 values of 5.54 and 5.24 respectively.

\section{Field efficacy of entomopathogenic fungi against $A$. craccivora}

The data on the field efficacy of fungal pathogens, B. bassiana, M. anisopliae and L. lecanii in comparison with the standard checks viz., monocrotophos $36 \mathrm{EC}$ and malathion $50 \mathrm{EC}$ against $M$. persicae showed significant variations among pre-treatment and post treatment counts (Table 3 and 4). The pre-treatment population ranged from $52.62-67.73 / 4 \mathrm{~cm}^{2}$ leaf area (Table 3 ). After the first spray, at 1 DAT, a significant reduction in the aphid population was observed in B. bassiana treatment. The $M$. anisopliae showed significantly less reduction of 1.23 per cent and was on par with the untreated check. The standard checks monocrotophos and malathion recorded significantly more reduction in aphid population than other treatments.

At 3 DAT, the same trend was observed in all the treatments. B. bassiana recorded 10.57 per cent reduction and $L$. lecanii recorded 2.34 per cent reduction. However, at 7 DAT, aphid population slowly increased in all the treatments. At 14 DAT, the population build up was relatively more than at 7 DAT in all the treatments. The mean percent reduction in the population at 14 DAT after first round of treatments was 13.32, 11.25, 81.43 and 79.87 per cent, respectively in B.bassiana, M. anisopliae, monocrotophos and malathion. From 
the data obtained, B. bassiana was found to be superior among the three fungal pathogens applied under field conditions and the standard checks gave best results against $M$. persicae (Table 3 ).

The aphid population on second round of treatments ranged between 23.72 to 73.86 aphids $/ 4 \mathrm{~cm}^{2}$ (Table 4). After second spraying, B. bassiana showed a reduction of 12.23 per cent and L. lecanii showed significantly less reduction of 3.72 per cent at 1 DAT. The population was significantly reduced to about 71.13 and 80.28 per cent in standard checks endosulfan and malathion, respectively. Similar trend was observed on 3 and 7 DAT. Though, there was increase in population at 14 DAT, the standard checks were superior to untreated check with a percent reduction of 82.23 and 81.26 in monocrotophos and malathion, respectively. After second round of treatments, the mean percent reduction in aphid population at 14 DAT observed in B. bassiana, M. anisopliae, L. Lecanii, monocrotophos and malathion were 27.37, 18.73, 2.75, 41.34 and 42.24 per cent, respectively (Table 4). The cadavers collected from B. bassiana treated plants alone produced characteristic mycelial growth in SMA+Y medium on incubation and it was not so in the cadavers collected from $L$. lecanii treatment.

The result obtained with respect to the effect of $B$. bassiana in reducing the population of chilli aphid is supported by the findings of B. bassiana on banana aphid Pentalonia nigronervosa, which caused 37.0 to 96.66 per cent mortality of adult aphids and established that this fungus showed the highest mortality of nymphs and adults [16]. B. bassiana isolate CPD11 was highly pathogenic to cowpea aphid, A. craccivora causing a mortality range of 58 to 91 per cent, seven days after treatment [17]. B. bassiana was highly effective in controlling $C$. lanigera population at 14 days after treatment [18].

\section{CONCLUSION}

The use of entomopathogenic fungi for the control of agricultural pests has long been recognized [19]. Despite their huge potential in biocontrol processes, the use of entomopathogenic fungi has been underestimated due to a lack of knowledge on their abilities. Moreover the efficacy of fungal pathogens in the field largely depends on extreme temperatures in the environment [20]. For future prospects, strategies to standardize the risk assessment of these fungal species as biopesticides are needed. Proper selection of strains with specific host target without having negative influence on non-target organisms is another major point of concern. Overall entomopathogenic fungi hold a promising role as a potential biopesticide for sustainable use in agriculture.

\section{REFERENCES}

[1] Singh, S.R. and Allen, D.J. 1980. Pests, diseases, resistance and protection in cowpea. Adv. Legume Sci. $8(2): 124-125$

[2] Koshy, G., Nandakumar, C. and Premila, K.S. 1987. Need based use of insecticides for the control of pests of cowpea in rice fallows of Kerala. J. Trop. Agric. 7(1): 25-27

[3] Kotadia, V. S. and Bhalani, P. A. 1992. Residual toxicity of some insecticides against Aphis craccivora Koch on cowpea crop. Gujarat Agricultural University Research Journal. 17: 161-164.

[4] Basu, A. N. and Banerjee, S. N. 1958. Aphids of economic plants of West Bengal. Indian Agric. 2: 89-112.

[5] Hill, D.S. 1987. Agricultural Insect Pests of Tropics and their control, Cambridge University Press, Cambridge, pp.208-209.

[6] Patil, A.S. 2002. Proceedings of State level seminar on pest management for sustainable agriculture. MAU, Parbhani, 6-7, pp.33-37.

[7] Saranya, S., Ushakumari, R., Sosamma Jacob and Babu, Philip, M. 2010. Efficacy of different entomopathogenic fungi against cowpea aphid, Aphis craccivora (Koch). J. Biopestic, 3(1): 138-142.

[8] Lomer, C. H. and Lomer, C.S. 1996. Laboratory techniques in insect pathology. Lubilosa Tech. Bull., No.3, CABI Bioscience, UK, 38p. 
[9] Butt, T. M. and Goettel, M. S. 2000. Bioassays of entomopathogenic fungi. In: Bioassays of entomopathogenic microbes and nematodes. Navon, A. and K. R. S. Ascher (Eds.). C. A. B. International, UK.380p.

[10] Abbott, W.S. 1925. A method for computing the effectiveness of an insecticide. J. Econ. Entomol. 18: 265267.

[11] Finney, D.J. 1971. Probit analysis, 3rd edn. Cambridge University Press, Cambridge, UK. 333p.

[12] Derakshan, A., Rabindra, R. J. and Ramunujam, B. 2007. Efficacy of different isolates of entomopathogenic fungi against Brevicoryne brassicae (Linnaeus) at different temperature and humidities. J. Biol. Control. 21(1): 65-72

[13] Karindah, S., Rahardjo, B.T. and Santoso, S. 1996. Virulence of the fungus Verticillium lecanii Zimmermann against Aphis gossypii Glover (Homoptera: Aphididae). Agrivita. 19(1): 30-34

[14] Nirmala, R., Ramanujam, B., Rabindra, R.J. and Rao, N.S. 2006. Effect of entomofungal pathogens on mortality of three aphid species. J. Biol. Control. 20(1): 89-94

[15] Hesketh, H., Alderson, P.G., Pye, B.J. and Pell, J. K. 2008. The development and multiple uses of a standardised bioassay method to select hypocelerean fungi from biological control of aphids. Biol. Control. 26(2): 242-255

[16] Mathew, M.J., Saju, K.A. and Venugopal, M.N. 1998. Efficacy of entomogenous fungi on biological suppression of Pentalonia nigronervosa f. caladii Vander Goot on cardamom. J. Spices and Arom. Crops. 7(1): 43-46

[17] Ekesi, S., Akpa, A.D., Onu, I. and Ogunlana, M.O. 2000. Entomopathogenicity of Beauveria bassiana and Metarhizium anisopliae to the cowpea aphid, Aphis craccivora Koch (Homoptera: Aphididae). Archives Phytopathol. Plant Prot. 33(2): 171-180

[18] Ramegowda, G.K., Vidya, M., Patil, R.K., Puttannavar, M.S. and Lingappa, S. 2007. Laboratory and field evaluation of some entomopathogenic fungi against sugarcane woolly aphid, Ceratovacuna lanigera Zehntner (Homoptera: Aphididae). J. Biol. Control. 21 (Special): 173-176

[19] Ferron, P., Fargues, J. and Riba, G. 1991. Fungi as microbial insecticides against pests. In: Handbook of Applied Mycology, Vol. 2. D. K. Arora, L. Ajelio and K. G. Mukerji (eds.), Marcel Dekker, New York, pp.665-706.

[20] Zimmermann, G. and Butin, H. 1973. Untersuchungen über die Hitze - und Trocken resistent holzbewohnender Pilze. Flora, 162: 393-419. 
Table 1. Pathogenicity of fungal pathogens on $M$. persicae

\begin{tabular}{|c|l|c|}
\hline S. No & \multicolumn{1}{|c|}{ Fungal pathogen } & \% mortality* \\
\hline 1 & B. bassiana & 33.75 \\
& & $(31.67)^{\mathrm{b}}$ \\
\hline 2 & M. anisopliae & 11.25 \\
& & $(12.73)^{\mathrm{d}}$ \\
\hline 3 & L. lecanii & 16.25 \\
& & $(18.45)^{\mathrm{c}}$ \\
\hline 4 & Monocrotophos & 84.30 \\
& & $(83.24)^{\mathrm{a}}$ \\
\hline 5 & Malathion & 78.75 \\
& & $(79.45)^{\mathrm{a}}$ \\
\hline 6 & Untreated check & 0.0 \\
& & $(0.93)^{\mathrm{d}}$ \\
\hline
\end{tabular}

In a column, means followed by a common letter are not statistically different by DMRT $(p=0.05)$ Values in parentheses are arc sine transformed values * Mean of four observations

Table 2. Probit analyses of concentration, time - mortality response of $M$. persicae to fungal pathogens

\begin{tabular}{|c|c|c|c|c|c|c|c|c|}
\hline \multirow{2}{*}{$\begin{array}{c}\text { Fungal } \\
\text { pathogen }\end{array}$} & \multicolumn{4}{|c|}{ Concentration- mortality response } & \multicolumn{4}{|c|}{ Time-mortality response } \\
\hline & $\begin{array}{c}\chi^{2} * \\
(\mathbf{p}= \\
\mathbf{0 . 0 5})\end{array}$ & $\begin{array}{l}\text { Slope } \\
\text { b } \pm \text { SE }\end{array}$ & $\begin{array}{c}\text { LC }_{50} \\
\left(\mathbf{x 1 0}^{6} \text { spores } / \mathrm{ml}\right)\end{array}$ & $\begin{array}{c}\text { Fiducial } \\
\text { limits }\end{array}$ & $\begin{array}{c}\chi^{2} * \\
(\mathbf{p}= \\
\mathbf{0 . 0 5})\end{array}$ & $\begin{array}{c}\text { Slope } \\
\text { b } \pm \text { SE }\end{array}$ & $\begin{array}{l}\mathbf{L T}_{\mathbf{5 0}} * * \\
\text { (Hours) }\end{array}$ & $\begin{array}{c}\text { Fiducial } \\
\text { limits }\end{array}$ \\
\hline B. bassiana & 8.41 & $\begin{array}{c}1.42 \pm \\
0.06\end{array}$ & 4.58 & $\begin{array}{c}2.27- \\
9.25\end{array}$ & 3.50 & $\begin{array}{c}2.21 \pm \\
0.75\end{array}$ & 73.15 & $\begin{array}{c}72.98- \\
94.65\end{array}$ \\
\hline $\begin{array}{c}\text { M. } \\
\text { anisopliae }\end{array}$ & 9.52 & $\begin{array}{c}0.34 \pm \\
0.12\end{array}$ & 3.47 & $\begin{array}{c}3.38- \\
7.23\end{array}$ & 2.64 & $\begin{array}{c}1.21 \pm \\
0.45\end{array}$ & 83.11 & $\begin{array}{c}70.28- \\
97.12\end{array}$ \\
\hline L. lecanii & 6.72 & $\begin{array}{c}0.52 \pm \\
0.59\end{array}$ & 2.84 & $\begin{array}{c}2.11- \\
4.52\end{array}$ & 5.24 & $\begin{array}{c}3.50 \pm \\
0.63\end{array}$ & 87.52 & $\begin{array}{c}53.62- \\
72.23\end{array}$ \\
\hline
\end{tabular}

* All lines are significantly a good fit at $\mathrm{p}=0.05$

** Tested at the higher dose of $1 \times 10^{8}$ spores $/ \mathrm{ml}$ 
Table 3. Efficacy of fungal pathogens against M. persicae - I spraying - Field Trial

\begin{tabular}{|c|c|c|c|c|c|c|c|c|c|c|c|}
\hline \multirow[b]{3}{*}{ Treatments } & \multicolumn{11}{|c|}{$\begin{array}{l}\text { Aphid population }\left(\mathrm{No} . / 4 \mathrm{~cm}^{2}\right) * \\
\text { Days after first spraying }\end{array}$} \\
\hline & \multirow[b]{2}{*}{$\begin{array}{c}\text { Pre } \\
\text { Treatment } \\
\text { count }\end{array}$} & \multicolumn{2}{|c|}{1} & \multicolumn{2}{|c|}{3} & \multicolumn{2}{|c|}{7} & \multicolumn{2}{|c|}{14} & \multicolumn{2}{|c|}{ Mean } \\
\hline & & $\begin{array}{l}\text { No. of } \\
\text { Aphids }\end{array}$ & $\begin{array}{c}\% \\
\text { reduction } \\
\text { over } \\
\text { untreated } \\
\text { check }\end{array}$ & $\begin{array}{l}\text { No. of } \\
\text { Aphids }\end{array}$ & $\begin{array}{c}\% \\
\text { reduction } \\
\text { over } \\
\text { untreated } \\
\text { check }\end{array}$ & $\begin{array}{l}\text { No. of } \\
\text { Aphids }\end{array}$ & $\begin{array}{c}\% \\
\text { reduction } \\
\text { over } \\
\text { untreated } \\
\text { check }\end{array}$ & $\begin{array}{l}\text { No. of } \\
\text { Aphids }\end{array}$ & $\begin{array}{c}\% \\
\text { reduction } \\
\text { over } \\
\text { untreated } \\
\text { check }\end{array}$ & $\begin{array}{l}\text { No. of } \\
\text { Aphids }\end{array}$ & $\begin{array}{c}\% \\
\text { reduction } \\
\text { over } \\
\text { untreated } \\
\text { check }\end{array}$ \\
\hline $\begin{array}{l}\text { B.bassiana } \\
\left(1 \times 10^{8} \text { spores } / \mathrm{ml}\right)\end{array}$ & 61.52 & 57.39 & $\begin{array}{c}5.82 \\
(12.02)^{\mathrm{c}}\end{array}$ & 62.27 & $\begin{array}{c}10.57 \\
(10.74)^{\mathrm{c}}\end{array}$ & 58.71 & $\begin{array}{c}23.52 \\
(27.83)^{\mathrm{c}}\end{array}$ & 84.13 & $\begin{array}{c}15.27 \\
(27.32)^{\mathrm{c}}\end{array}$ & 76.49 & $\begin{array}{c}13.32 \\
(23.26)^{\mathrm{c}}\end{array}$ \\
\hline $\begin{array}{l}\text { M. anisopliae } \\
\left(1 \times 10^{8} \text { spores } / \mathrm{ml}\right)\end{array}$ & 57.37 & 54.93 & $\begin{array}{c}1.23 \\
(7.21)^{\mathrm{d}}\end{array}$ & 57.24 & $\begin{array}{c}1.92 \\
(5.59)^{\mathrm{d}}\end{array}$ & 51.28 & $\begin{array}{c}17.24 \\
(24.24)^{\mathrm{d}}\end{array}$ & 73.96 & $\begin{array}{c}19.22 \\
(26.24)^{\mathrm{d}}\end{array}$ & 62.31 & $\begin{array}{c}11.25 \\
(20.32)^{\mathrm{d}}\end{array}$ \\
\hline $\begin{array}{l}\text { L. lecanii } \\
\left(1 \times 10^{8} \text { spores } / \mathrm{ml}\right)\end{array}$ & 52.62 & 53.87 & $\begin{array}{c}1.73 \\
(7.68)^{\mathrm{d}} \\
\end{array}$ & 62.43 & $\begin{array}{c}2.34 \\
(6.59)^{\mathrm{e}} \\
\end{array}$ & 62.53 & $\begin{array}{c}0.24 \\
(2.81)^{\mathrm{e}} \\
\end{array}$ & 87.48 & $\begin{array}{c}1.24 \\
(5.48)^{\mathrm{e}} \\
\end{array}$ & 72.23 & $\begin{array}{c}1.42 \\
(6.47)^{\mathrm{e}} \\
\end{array}$ \\
\hline $\begin{array}{l}\text { Monocrotophos } \\
(2 \mathrm{ml} / \text { lit) }\end{array}$ & 64.20 & 32.36 & $\begin{array}{c}74.90 \\
(62.12)^{\mathrm{a}} \\
\end{array}$ & 23.42 & $\begin{array}{c}72.82 \\
(68.34)^{a} \\
\end{array}$ & 11.48 & $\begin{array}{c}77.20 \\
(61.47)^{\mathrm{a}} \\
\end{array}$ & 32.82 & $\begin{array}{c}62.40 \\
(52.30)^{\mathrm{a}} \\
\end{array}$ & 25.35 & $\begin{array}{c}81.43 \\
(73.54)^{a} \\
\end{array}$ \\
\hline $\begin{array}{l}\text { Malathion } \\
(2 \mathrm{ml} / \mathrm{lit})\end{array}$ & 52.68 & 38.54 & $\begin{array}{c}72.50 \\
(57.67)^{\mathrm{b}}\end{array}$ & 28.54 & $\begin{array}{c}76.40 \\
(65.26)^{\mathrm{b}}\end{array}$ & 12.25 & $\begin{array}{c}70.50 \\
(57.10)^{\mathrm{b}}\end{array}$ & 34.26 & $\begin{array}{c}71.62 \\
(60.23)^{b}\end{array}$ & 22.47 & $\begin{array}{c}79.87 \\
(61.82)^{b}\end{array}$ \\
\hline Untreated check & 67.73 & 70.27 & - & 62.43 & - & 65.40 & - & 85.14 & - & 73.45 & - \\
\hline
\end{tabular}

In a column, means followed by a common letter are not statistically different by DMRT $(\mathrm{p}=0.05)$

Values in parentheses are arc sine transformed values * Mean of four observations 
Table 4. Field efficacy of fungal pathogens against M. persicae - II spraying

\begin{tabular}{|c|c|c|c|c|c|c|c|c|c|c|c|}
\hline \multirow[b]{3}{*}{ Treatments } & \multicolumn{11}{|c|}{ Aphid population $\left(\mathrm{No} . / 4 \mathrm{~cm}^{2}\right) *$ Days after first spraying } \\
\hline & \multirow[b]{2}{*}{$\begin{array}{c}\text { Pre } \\
\text { Treatment } \\
\text { count }\end{array}$} & \multicolumn{2}{|c|}{1} & \multicolumn{2}{|c|}{$\mathbf{3}$} & \multicolumn{2}{|c|}{7} & \multicolumn{2}{|c|}{14} & \multicolumn{2}{|c|}{ Mean } \\
\hline & & $\begin{array}{l}\text { No. of } \\
\text { Aphids }\end{array}$ & $\begin{array}{c}\% \\
\text { reduction } \\
\text { over } \\
\text { untreated } \\
\text { check }\end{array}$ & $\begin{array}{l}\text { No. of } \\
\text { Aphids }\end{array}$ & $\begin{array}{c}\% \\
\text { reduction } \\
\text { over } \\
\text { untreated } \\
\text { check } \\
\end{array}$ & $\begin{array}{l}\text { No. of } \\
\text { Aphids }\end{array}$ & $\begin{array}{c}\% \\
\text { reduction } \\
\text { over } \\
\text { untreated } \\
\text { check } \\
\end{array}$ & $\begin{array}{l}\text { No. of } \\
\text { Aphids }\end{array}$ & $\begin{array}{c}\% \\
\text { reduction } \\
\text { over } \\
\text { untreated } \\
\text { check }\end{array}$ & $\begin{array}{l}\text { No. of } \\
\text { Aphids }\end{array}$ & $\begin{array}{c}\% \\
\text { reduction } \\
\text { over } \\
\text { untreated } \\
\text { check } \\
\end{array}$ \\
\hline $\begin{array}{l}\text { B.bassiana } \\
\left(1 \times 10^{8} \text { spores } / \mathrm{ml}\right)\end{array}$ & 71.23 & 62.36 & $\begin{array}{c}12.23 \\
(20.64)^{\mathrm{c}} \\
\end{array}$ & 76.42 & $\begin{array}{c}13.42 \\
(21.27)^{\mathrm{c}} \\
\end{array}$ & 82.58 & $\begin{array}{c}17.37 \\
(19.47)^{\mathrm{c}} \\
\end{array}$ & 64.26 & $\begin{array}{c}27.37 \\
(22.46)^{\mathrm{b}} \\
\end{array}$ & 75.75 & $\begin{array}{c}15.24 \\
(21.94)^{\mathrm{b}} \\
\end{array}$ \\
\hline $\begin{array}{l}\text { M.anisopliae } \\
\left(1 \times 10^{8} \text { spores } / \mathrm{ml}\right)\end{array}$ & 73.86 & 69.55 & $\begin{array}{c}9.62 \\
(18.24)^{\mathrm{d}} \\
\end{array}$ & 74.24 & $\begin{array}{c}11.42 \\
(26.12)^{\mathrm{d}} \\
\end{array}$ & 65.36 & $\begin{array}{c}11.24 \\
(23.76)^{\mathrm{d}} \\
\end{array}$ & 66.82 & $\begin{array}{c}18.37 \\
(19.26)^{\mathrm{c}} \\
\end{array}$ & 73.84 & $\begin{array}{c}10.23 \\
(18.52)^{\mathrm{c}} \\
\end{array}$ \\
\hline $\begin{array}{l}\text { L.lecanii } \\
\left(1 \times 10^{8} \text { spores } / \mathrm{ml}\right)\end{array}$ & 77.38 & 73.33 & $\begin{array}{c}3.72 \\
(8.74)^{\mathrm{e}}\end{array}$ & 77.38 & $\begin{array}{c}3.46 \\
(8.78)^{\mathrm{e}} \\
\end{array}$ & 75.13 & $\begin{array}{c}3.26 \\
(9.23)^{\mathrm{e}}\end{array}$ & 72.45 & $\begin{array}{c}2.75 \\
(6.36)^{\mathrm{d}} \\
\end{array}$ & 78.33 & $\begin{array}{c}4.32 \\
(8.56)^{d}\end{array}$ \\
\hline $\begin{array}{l}\text { Monocrotophos } \\
(2 \mathrm{ml} / \mathrm{lit})\end{array}$ & 23.72 & 8.44 & $\begin{array}{c}82.23 \\
(66.42)^{b}\end{array}$ & 6.77 & $\begin{array}{c}75.53 \\
(63.44)^{\mathrm{a}} \\
\end{array}$ & 8.35 & $\begin{array}{c}64.27 \\
(50.16)^{\mathrm{a}} \\
\end{array}$ & 24.58 & $\begin{array}{c}41.34 \\
(40.36)^{\mathrm{a}} \\
\end{array}$ & 10.67 & $\begin{array}{c}64.23 \\
(54.82)^{\mathrm{a}} \\
\end{array}$ \\
\hline $\begin{array}{l}\text { Malathion } \\
(2 \mathrm{ml} / \text { lit })\end{array}$ & 27.36 & 6.27 & $\begin{array}{c}81.26 \\
(64.62)^{\mathrm{a}} \\
\end{array}$ & 7.52 & $\begin{array}{c}72.52 \\
(56.27)^{b}\end{array}$ & 10.42 & $\begin{array}{c}59.57 \\
(52.29)^{\mathrm{b}} \\
\end{array}$ & 26.34 & $\begin{array}{c}42.24 \\
(41.83)^{\mathrm{a}} \\
\end{array}$ & 12.73 & $\begin{array}{c}64.57 \\
(56.47)^{\mathrm{a}} \\
\end{array}$ \\
\hline Untreated check & 75.64 & 81.33 & - & 73.78 & - & 83.52 & - & 83.36 & - & 85.67 & - \\
\hline
\end{tabular}

In a column, means followed by a common letter are not statistically different by DMRT $(\mathrm{p}=0.05)$

Values in parentheses are arc sine transformed values * Mean of four observations 